\title{
Wild Allium species (Alliaceae) used in folk medicine of Tajikistan and Uzbekistan
}

\author{
Michael Keusgen*1, Reinhard M Fritsch², Hikmat Hisoriev², \\ Parvina A Kurbonova ${ }^{3}$ and Furkat O Khassanov ${ }^{4}$
}

\begin{abstract}
Address: ${ }^{1}$ Philipps-Universität Marburg, Institut für Pharmazeutische Chemie, Marbacher Weg 6, D-35032, Marburg, ${ }^{2}$ Institut für Pflanzengenetik und Kulturpflanzenforschung, Corrensstraße 3, D-06466, Gatersleben, ${ }^{3}$ Botanical Institute of the Tajik Academy of Sciences, Karamov Street 27 , 734017 Dushanbe, Republic of Tajikistan and ${ }^{4}$ Scientific Centre of Plant Production "Botanika" of the Uzbek Academy of Sciences, F. Khodzhaev Street 32, 700143 Tashkent, Republic of Uzbekistan

Email: Michael Keusgen* - keusgen@staff.uni-marburg.de; Reinhard M Fritsch - fritschr@ipk-gatersleben.de; Hikmat Hisoriev - hhikmat@mail.ru; Parvina A Kurbonova - hhikmat@mail.ru; Furkat O Khassanov - khasanov@ars-inform.uz

* Corresponding author
\end{abstract}

Published: 03 April 2006

Journal of Ethnobiology and Ethnomedicine 2006, 2:18 doi:10.1186/1746-4269-2-18
Received: 23 January 2006

Accepted: 03 April 2006

This article is available from: http://www.ethnobiomed.com/content/2/I/18

(c) 2006 Keusgen et al; licensee BioMed Central Ltd.

This is an Open Access article distributed under the terms of the Creative Commons Attribution License (http://creativecommons.org/licenses/by/2.0), which permits unrestricted use, distribution, and reproduction in any medium, provided the original work is properly cited.

\begin{abstract}
Background: Hitherto available sources from literature mentioned several wild growing Allium species as "edible" or "medicinally used" but without any further specification.

Methods: New data were gained during recent research missions: Allium plants were collected and shown to the local population which was asked for names and usage of these plants.

Results: Information was collected about current medical applications of sixteen wild species, nine of which belong to different sections of Allium subgenus Melanocrommyum. These plants are used against headache, cold, and stomach problems, and are mostly applied fresh or after boiling.

Conclusion: Close taxonomic relatives of the common onion were used similar to cultivated onion species, but medical use like garlic was mostly reported for species taxonomically not related to garlic.
\end{abstract}

\section{Background}

About 200 different Allium species were reported for the mountainous regions of Middle and South-West Asia [1]. The use of especially tasteful and curative members of this family has a long tradition in several Asian populations with apparently deep historical roots. This assumption might be illustrated by the fact that also people living in urban areas since generations know how to prepare special dishes from particular plants. They are buying the required plant material at local markets where it is sold by rural providers which collected it in the wild. Also ancient reports about common onion (Allium cepa L.) and garlic
(A. sativum L.) are coming out of this area bearing antique civilizations. While wild ancestors of the worldwide most important cultivated Allium species could not be identified yet without doubt, genetically and phylogenetically most closely related plants are exclusively distributed in this part of Asia [2].

The economically most important Allium crop species (common onion and garlic) are worldwide used as spices, vegetables, and medicinal plants. Traditionally, they play a very important role in the daily diet also in Asia. Here they can be seen under cultivation in every home garden. 


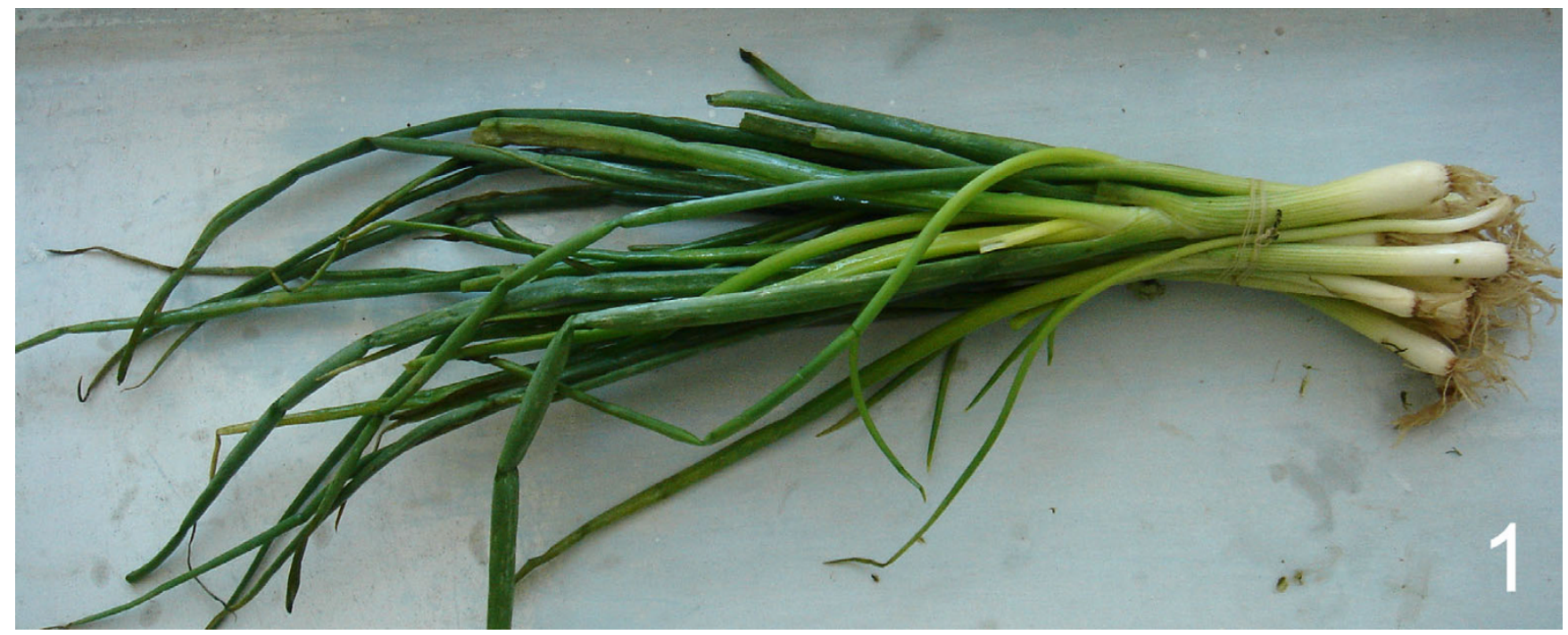

Figure I

Sample figure title. Young plants of common onion are frequently eaten as greens and sold on nearly every local market (photo taken in Dushanbe, Tajikistan).

This holds also true for the territories of Tajikistan and Uzbekistan where young fresh plants (Fig. 1) and dry bulbs are offered at every local market and are generally also used as medicinal plants. A rather recent review [3] described the wide spectrum of medical properties of both crop species.

Besides theses two cultivated species, also a number of wild species are collected and eaten by the local population [4] but separate references to medical applications are rarely given $[5,6]$. Most literature sources mention only that particular species were eaten, emit a characteristic smell like onion or garlic, or are used as spice or medicinal plants without presenting further details. Sometimes the use of wild Allium species is described as 'used as common onion'. Again, this description is very diffuse und means, that some parts of the plant can be either used as vegetable, spice, or herbal drug. Also a differentiation between true vegetable plants and spicy vegetables (e.g., leek A. porrum L. in Europe and North America) is rarely given.

Detailed information is not even supplied for widely used species. An exception is the dissertation of Umarov [7]. In Tajikistan and in some parts of neighbouring countries where related tribes settled, leaves of $A$. rosenbachianum auct. - this name is used in some scientific literature for $A$. rosenbachianum (Fig. 2) in a strict sense as well as for $A$. rosenorum (Fig. 3) - are extensively used for traditional dishes. According to literature $[8,9]$, this species is applied as spice and as vegetable as ingredient of soups. In the 1980ies during botanical expeditions, one of the authors (RMF) was repeatedly informed by local people that these leaves, which do not own any special taste, are often collected and eaten because consumption "refreshes the body after the winter period". Thus, the reported use as spice needs confirmation or exclusion.

Another example for confusing reports in literature is related to A. stipitatum. Information about the use of this species is in accordance for both countries that only young bulbs were pickled and highly esteemed as spicy vegetable $[6,10]$. A medicinal use was not reported yet but could not be surely excluded. Wild species listed above can be obtained at local markets throughout.

Sensoric properties as well as health benefits of Allium species can be related to a broad variety of secondary metabolites of these plants. Most important are sulphur compounds, which are typically alk(en)yl sulphoxides of the amino acid cysteine. If plant material is damaged, the enzyme alliinase comes in contact with cysteine sulphoxides like methiin, alliin, isoalliin, and propiin, and a broad variety of biologically active compounds is formed [3]. Variations in the combination and concentration of enzymatically formed sulphur compounds result in species- and group-specific taste and smell. Also the health benefit of Allium species can be deduced from sulphur components. If the concentration of sulphur compounds is rather low, species were often used as vegetable giving a 


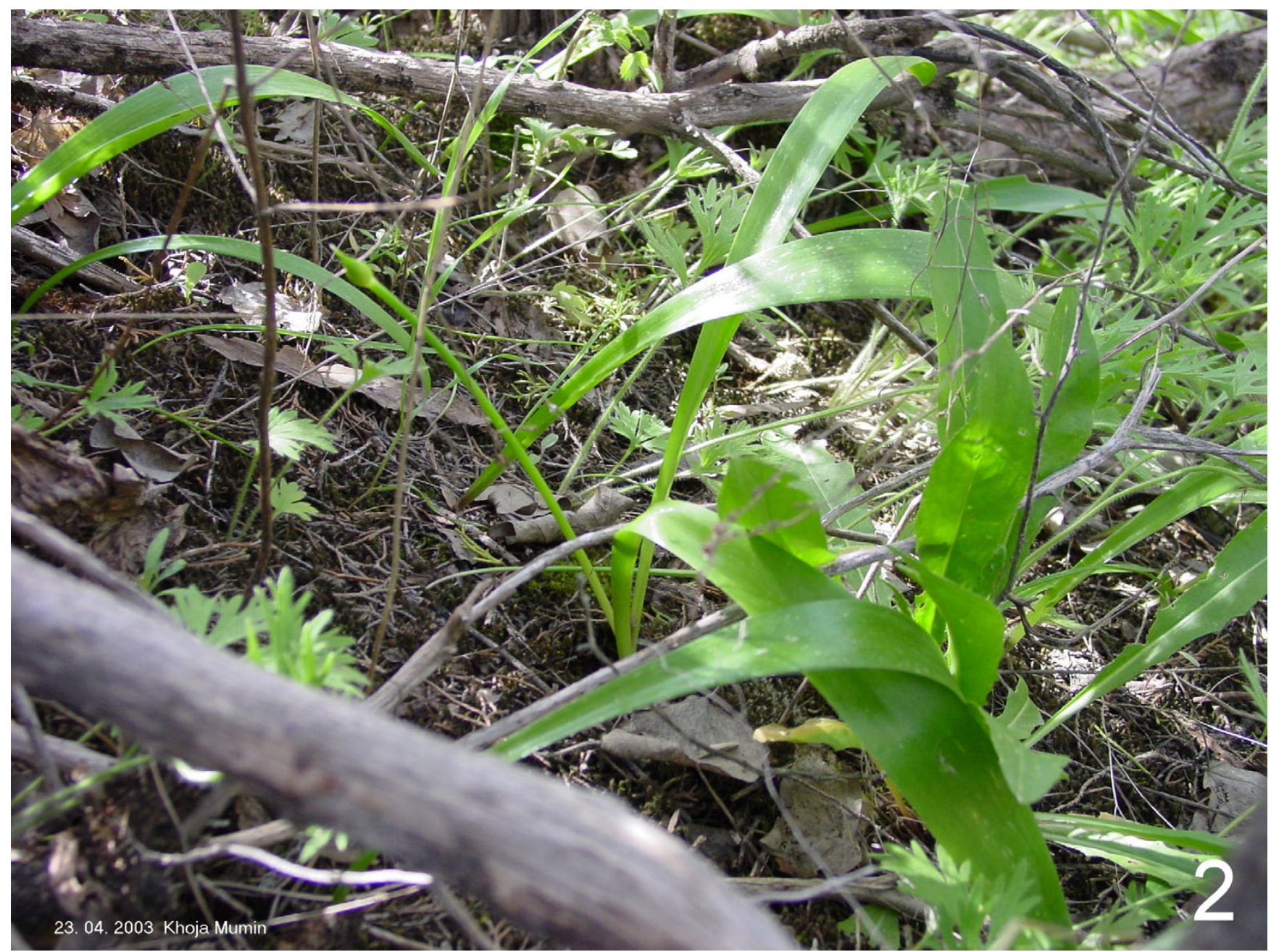

Figure 2

Another sample figure title. Allium rosenbachianum: leaves of this size are collected for consumption (photo taken in South Tajikistan).

very mild taste after cocking. Species with a high sulphur content like garlic were mainly used as spice and/or medicinal plant.

Besides sulphur compounds, also saponins were reported for a number of Allium species and may also contribute to the health benefits of these plants [3]. Sugars, typically fructose, are responsible for the sweet taste of a number of Allium species, mostly related to A. cepa. Moreover, phenolic compounds were detected in this genus and must be considered as bioactive compounds, too.

Not one of these publications mentioned in Table 1 gives any reference about the scientific background of the data and presented vouchers (photographs, herbarium specimens, or other stored material) or described identification of the plants. Therefore, a research project was initiated for collecting new data, which follows another strategy to minimize error sources. The currently available results are presented below.

\section{Methods}

Information was gained during joined research missions with the local cooperation partners in 2003, 2004, and 2005. In the areas of interest, at first fresh plant material was collected and then shown to the native population of this region (mountainous areas of the Republics of Uzbekistan and Tajikistan, mainly belonging to the Hissar mountain range and the Pamir). Because of strict ethnological rules, only male person were asked, but these often showed plant material to further members of the family, also female persons. People were interviewed in their native language. Because of significant migrations during the time of the former Soviet Union, results were not 


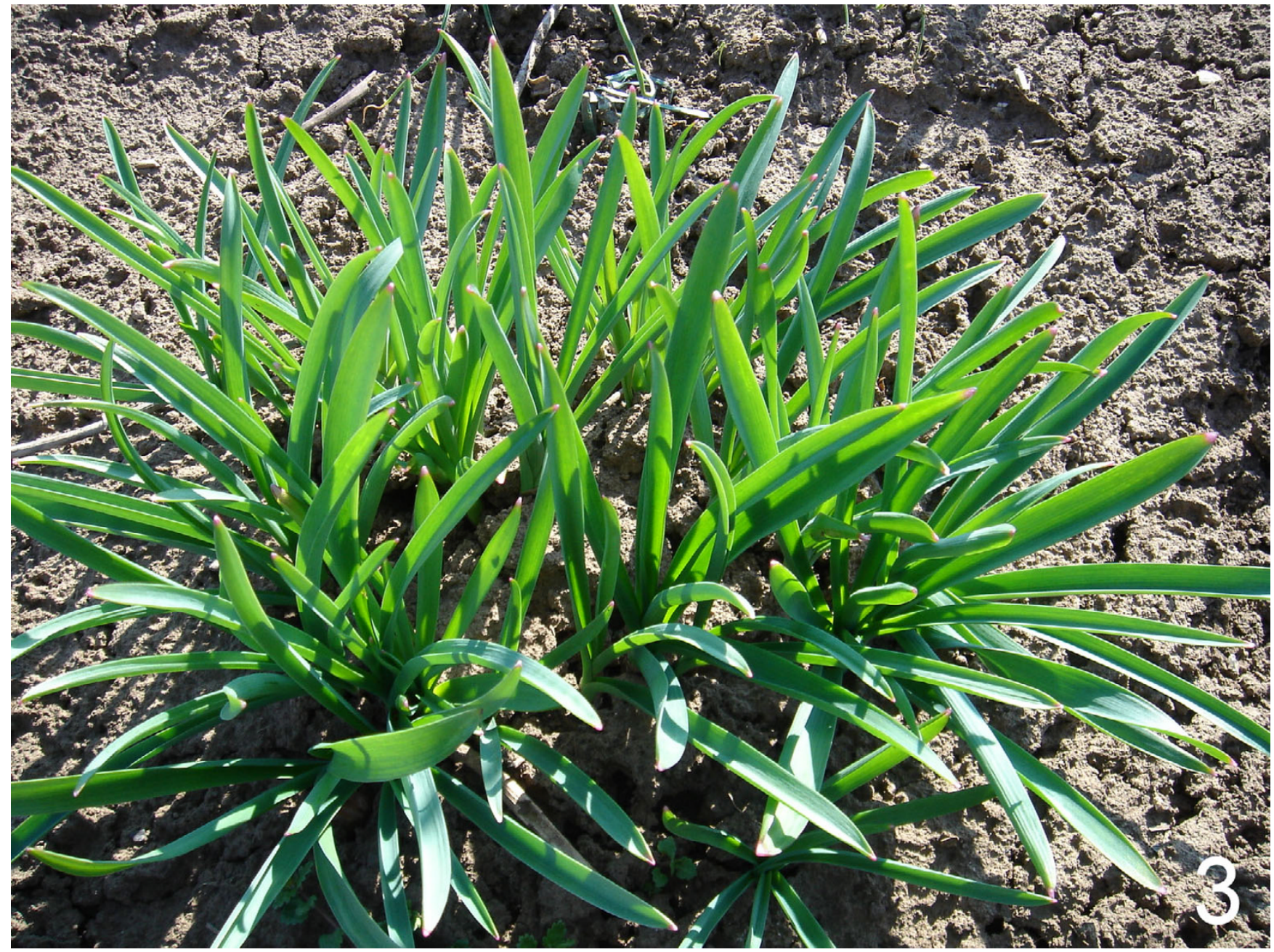

Figure 3

Another sample figure title. Allium rosenorum: leaves of the given size are collected for consumption (photo taken from the reference collection).

related to specific ethnological sub-populations. Also, results were not related to the age of interviewed persons, but in most cases they had an age of about 50 to 60 years and were often recommended by rural communities as experts for traditionally used plants. People were asked about the local name and whether they are using these plants, and if so, which part is taken, for what purpose, and how is it prepared and stored.

Afterwards, the presented plant material was transferred to the national living Allium collections of Tajikistan in Dushanbe (curator: Prof. Dr. H. Hisoriev, accessions beginning with ' 6 '), or of Uzbekistan in Tashkent (curator: Dr. F. Khassanov, accessions beginning with '4'), resp., for further cultivation, documentation, and taxonomic determination. In Tashkent and Dushanbe also voucher specimens of the accessions are deposited. Duplicates of some accessions were also transferred to the Taxonomic Allium Reference Collection of the Institute of Plant Genetics and Crop Plant Research (IPK), Gatersleben, Germany, to be re-determined if necessary. All data concerning collecting, cultivation, and questioning the native population were assembled in an electronic database.

If possible, results from interviews were compared with data available from literature as indicated in Table 1. It must be noticed, that most literature data do lack an unambiguous botanical description of plant material. 
Table I: Medical application of wild Allium species in Tajikistan and Uzbekistan

\begin{tabular}{|c|c|c|c|c|c|}
\hline Local Name & Application & Region of Usage & Nationality & Accessions & Source \\
\hline \multicolumn{6}{|c|}{ subgenus Rhizirideum (G. Don ex Koch) Wendelbo section Cepa (Mill.) Prokh. } \\
\hline \multicolumn{6}{|c|}{ Allium oschaninii O. Fedt. } \\
\hline piozi kuhi & $\begin{array}{l}\text { Leaves and bulbs are used against fever, } \\
\text { headache, kidney problems, and stomach-ache. }\end{array}$ & $\begin{array}{l}\text { Central Tajikistan, } \\
\text { Darvaz mountain } \\
\text { range }\end{array}$ & Tajik & 6080,6100 & 12 \\
\hline \multicolumn{6}{|c|}{ Allium pskemense B. Fedt. } \\
\hline & The bulb juice is used as a medicine. & $\begin{array}{l}\text { Uzbekistan: West } \\
\text { Tianshan mountain } \\
\text { range }\end{array}$ & (not reported) & (no vouchers given) & 10 \\
\hline \multirow[t]{2}{*}{ tog pioz } & $\begin{array}{l}\text { The whole fresh plants and bulb juice are used } \\
\text { against stomach problems, tuberculosis, and, } \\
\text { like boiled bulbs, against strong cold. Young } \\
\text { leaves and stems or boiled and smashed bulbs } \\
\text { are applied to wounds and against skin diseases. }\end{array}$ & $\begin{array}{l}\text { Uzbekistan: West } \\
\text { Tianshan mountain } \\
\text { range }\end{array}$ & Uzbek & 4142 & 14 \\
\hline & $\begin{array}{l}\text { The bulb juice is used against tuberculosis and } \\
\text { strong cold. }\end{array}$ & Central Asia & (not reported) & (no vouchers given) & 15 \\
\hline \multicolumn{6}{|c|}{ subgenus Rhizirideum section Campanulata Kamelin } \\
\hline \multicolumn{6}{|c|}{ Allium barsczewskii Lipsky } \\
\hline $\operatorname{sir}$ & $\begin{array}{l}\text { Bulbs and pounded leaves are applied at the } \\
\text { head against colds and flue, headache, fever, and } \\
\text { toothache. Seeds are eaten with bread in order } \\
\text { to increase appetite. }\end{array}$ & $\begin{array}{l}\text { Central Tajikistan: } \\
\text { Vakhsh mountain } \\
\text { range }\end{array}$ & Tajik & 6105 & 14 \\
\hline \multicolumn{6}{|c|}{ Allium jodanthum Vved. } \\
\hline piozi dashti & $\begin{array}{l}\text { Fried bulbs are laid onto the face in case of } \\
\text { nerve problems; fresh bulbs are used against } \\
\text { toothache. }\end{array}$ & $\begin{array}{l}\text { Tajikistan: Panj } \\
\text { Karatau Mts. }\end{array}$ & Tajik & 6040 & 12 \\
\hline yovoj pioz & $\begin{array}{l}\text { Leaves and bulbs without stems are used against } \\
\text { toothache and mumps, alcoholic extracts for } \\
\text { disinfections of wounds. }\end{array}$ & $\begin{array}{l}\text { Uzbekistan: West } \\
\text { Tianshan Mts. }\end{array}$ & Uzbek & $4|4|, 4 \mid 88$ & 14 \\
\hline \multicolumn{6}{|c|}{ subgenus Rhizirideum section Oreiprason F. Herm. } \\
\hline \multicolumn{6}{|c|}{ Allium talassicum Regel } \\
\hline & Any medicinal usage denied. & $\begin{array}{l}\text { Uzbekistan: West } \\
\text { Tianshan mountain } \\
\text { range }\end{array}$ & Uzbek & 4217 & 14 \\
\hline & Used in folk's medicine (not specified). & $\begin{array}{l}\text { Uzbekistan: West } \\
\text { Tianshan mountain } \\
\text { range }\end{array}$ & (not reported) & (no vouchers given) & 10 \\
\hline \multirow[t]{2}{*}{ dasht-niyaz } & $\begin{array}{l}\text { Bulbs are used against scurvy and for health } \\
\text { recovery. }\end{array}$ & Central Asia & (not reported) & (no vouchers given) & 15 \\
\hline & $\begin{array}{l}\text { Bulbs are used against scurvy and for health } \\
\text { recovery. }\end{array}$ & Tajikistan & (not reported) & (no vouchers given) & 16 \\
\hline \multicolumn{6}{|c|}{ subgenus Rhizirideum section Schoenoprasum Dumort. } \\
\hline \multicolumn{6}{|c|}{ Allium fedschenkoanum Regel } \\
\hline qamch pioz & $\begin{array}{l}\text { Dried plants are cut and burnt, and the smoke is } \\
\text { inhaled against cold. }\end{array}$ & $\begin{array}{l}\text { Central Tajikistan: } \\
\text { Darvaz mountain } \\
\text { range }\end{array}$ & Tajik & 6197 & 12 \\
\hline \multicolumn{6}{|c|}{ subgenus Allium section Allium } \\
\hline \multicolumn{6}{|c|}{ Allium filidens Regel } \\
\hline piozi diona & Bulbs are applied against headache. & $\begin{array}{l}\text { Tajikistan: Darvaz } \\
\text { mountain range }\end{array}$ & Tajik & 6069 & 12 \\
\hline \multicolumn{6}{|c|}{ subgenus Melanocrommyum (Webb et Berth.) Rouy str. } \\
\hline \multicolumn{6}{|c|}{ Allium chitralicum Wang et Tang s. } \\
\hline siri kuhi & $\begin{array}{l}\text { Smashed bulbs are used against sense of fear, } \\
\text { and the whole plant for the national dish 'atolla'. }\end{array}$ & Tajikistan: West Pamir & Tajik & 6097 & 12 \\
\hline \multicolumn{6}{|c|}{ Allium hissaricum Vved. } \\
\hline $\operatorname{sir}$ & $\begin{array}{l}\text { Fresh or dried leaves are applied against } \\
\text { headache and fever. }\end{array}$ & Central Tajikistan & Tajik & 6106 & 12 \\
\hline \multicolumn{6}{|c|}{ Allium karataviense Regel } \\
\hline & Applied as medicine (not specified). & $\begin{array}{l}\text { Uzbekistan: West } \\
\text { Tianshan mountain } \\
\text { range }\end{array}$ & (not reported) & (no vouchers given) & 10 \\
\hline & Applied for quicker healing of wounds. & North Tajikistan & (not reported) & (no vouchers given) & 5 \\
\hline
\end{tabular}


Table I: Medical application of wild Allium species in Tajikistan and Uzbekistan (Continued)

\begin{tabular}{|c|c|c|c|c|c|}
\hline & Used against pneumonia and lung problems. & Central Asia & (not reported) & (no vouchers given) & 15 \\
\hline \multicolumn{6}{|c|}{ Allium komarowii Lipsky } \\
\hline gushi gurgak & Used as an anabolic for horses. & $\begin{array}{l}\text { Tajikistan: Hissar } \\
\text { mountain range }\end{array}$ & Tajik & 6134 & 12 \\
\hline khujrak-motor & $\begin{array}{l}\text { Leaves and bulbs are fresh used, or cut in pieces } \\
\text { and cooked and applied against anaemia and bad } \\
\text { circulation. }\end{array}$ & $\begin{array}{l}\text { Uzbekistan: West } \\
\text { Hissar mountain range }\end{array}$ & Uzbek & 4170 & 14 \\
\hline \multicolumn{6}{|c|}{ Allium motor Kamelin et Levichev } \\
\hline motor & $\begin{array}{l}\text { In spring the leaves are highly esteemed as } \\
\text { stuffing for a special variant of the national pie } \\
\text { dish 'somsa', medical properties not mentioned. }\end{array}$ & $\begin{array}{l}\text { Uzbekistan: West } \\
\text { Tianshan mountain } \\
\text { range }\end{array}$ & (not reported) & (no vouchers given) & 10 \\
\hline moj-modor & $\begin{array}{l}\text { Young leaves are eaten in soups and 'somsa' } \\
\text { which owns a specific activity as tonic. }\end{array}$ & $\begin{array}{l}\text { Uzbekistan: West } \\
\text { Tianshan mountain } \\
\text { range }\end{array}$ & Uzbek & 4133 & 14 \\
\hline \multicolumn{6}{|c|}{ Allium rosenbachianum Regel subsp. rosenbachianum and subsp. kwakense R.M. Fritsch } \\
\hline & $\begin{array}{l}\text { Young leaves are used as condiment for soups, } \\
\text { no medical properties mentioned. }\end{array}$ & Central Tajikistan & (not reported) & (no vouchers given) & 6 \\
\hline gushi buzak & $\begin{array}{l}\text { Fresh and dried leaves represent the vegetable } \\
\text { part of the national soup dish 'atolla' which is } \\
\text { much esteemed as appetizer and general tonic. }\end{array}$ & $\begin{array}{l}\text { Central Tajikistan: } \\
\text { Panj Karatau Mts., } \\
\text { Darvaz and Vakhsh } \\
\text { mountain ranges }\end{array}$ & Tajik & $\begin{array}{l}6050,6051,6072 \\
6078,6107\end{array}$ & 12 \\
\hline \multicolumn{6}{|c|}{ Allium rosenorum R.M. Fritsch (A. rosenbachianum auct.) } \\
\hline $\begin{array}{l}\text { siekhalaf, siralaf, } \\
\text { shipioz, jorji }\end{array}$ & $\begin{array}{l}\text { Young fresh or dried leaves are used for the } \\
\text { national soup dishes 'atolla' and 'oshi sioalaf' } \\
\text { which have tonic properties. }\end{array}$ & $\begin{array}{l}\text { Central Tajikistan: } \\
\text { Vakhsh and Hissar } \\
\text { mountain ranges }\end{array}$ & Tajik & $6109,6143,6167$ & 12 \\
\hline siohalaf & $\begin{array}{l}\text { Young leaves are used as condiment for soups, } \\
\text { no medical properties mentioned. }\end{array}$ & Central Tajikistan & (not reported) & (no vouchers given) & 6 \\
\hline \multicolumn{6}{|c|}{ Allium severtzovioides R.M. Fritsch } \\
\hline tosh-motor & $\begin{array}{l}\text { Fresh leaves and bulbs without stems are locally } \\
\text { applied against stomach and duodenum diseases. }\end{array}$ & $\begin{array}{l}\text { Uzbekistan: West } \\
\text { Tianshan mountain } \\
\text { range }\end{array}$ & Uzbek & 4140 & 14 \\
\hline \multicolumn{6}{|c|}{ Allium suworowii Regel } \\
\hline & Used in folk's medicine (not specified). & North Tajikistan & (not reported) & (no vouchers given) & 5 \\
\hline & Used as a medicine (not specified). & $\begin{array}{l}\text { Uzbekistan: West } \\
\text { Tianshan mountain } \\
\text { range }\end{array}$ & (not reported) & (no vouchers given) & 10 \\
\hline piozi anzur & $\begin{array}{l}\text { Decocts of flowers and seeds are applied against } \\
\text { headache and cold. }\end{array}$ & $\begin{array}{l}\text { Central Tajikistan: } \\
\text { Darvaz mountain } \\
\text { range }\end{array}$ & Tajik & 6090 & 12 \\
\hline \multirow[t]{2}{*}{ niyazi-ansul } & $\begin{array}{l}\text { Pickled bulbs are eaten against tuberculosis and } \\
\text { bronchitis. }\end{array}$ & Central Asia & (not reported) & (no vouchers given) & 15 \\
\hline & $\begin{array}{l}\text { Used in folk's medicine against early forms of } \\
\text { tuberculosis and bronchitis. }\end{array}$ & $\begin{array}{l}\text { Tajikistan (not } \\
\text { specified) }\end{array}$ & (not reported) & (no vouchers given) & 16 \\
\hline
\end{tabular}

Also, specific plant parts (leaves, bulbs, stems) used by men were not mentioned in most cases. This lack of former knowledge was closed by the now presented study.

\section{Results}

The obtained data confirm that a remarkable number of wild Allium species is collected for consumption by Uzbek and Tajik people. Inside the visited countries, no further differentiation into ethnic groups was done. Several species are only used as vegetable and/or spice plants. They have special importance in rural areas during springtime when vegetables cannot be bought in the shops or are too expensive, and the garden plots do not give yield yet. Such species will be not considered here, because investigations are ongoing. Other wild Allium species are eaten due to a special health benefit, or applied in case of medical indications (see Table 1).

\section{Discussion}

Three wild Allium species growing in Tajikistan and Uzbekistan (A. oschaninii, A. pskemense, A. praemixtum) are closely related to common onion. They are traditionally collected and used as spice like common onion, but only A. oschaninii and A. pskemense are also medicinally applied. Thus, we can confirm reports about the use of $A$. oschaninii in Uzbekistan and Tajikistan $[4,6,8,10]$. We can also verify that $A$. pskemense is sometimes grown in home gardens in Uzbekistan (Fig. 4) for usage like common onion and as medicinal plant. 


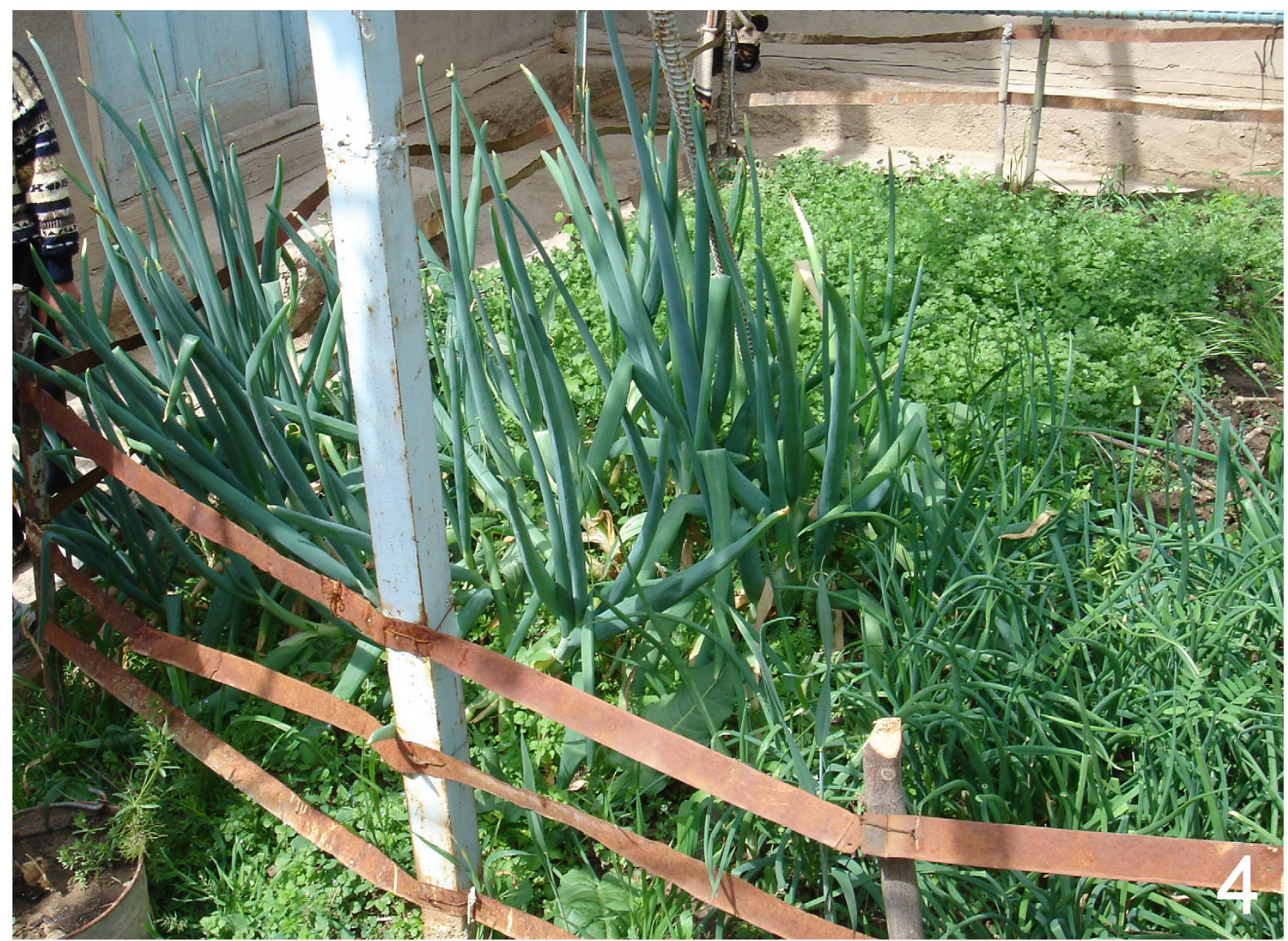

Figure 4

Another sample figure title. Allium pskemense (left) and common onion (right) are jointly grown in a home garden near Tashkent (Uzbekistan).

Although the only species of subgenus Allium mentioned in Tab. 1 (A. filidens) is taxonomically rather distantly related to garlic, but it is medically used in a similar manner. This kind of medical applications also holds true for two species from the rhizomatous section Campanulata and for four species from the bulbous subgenus Melanocrommyum. This usage is apparently not strictly related to the content of the cysteine sulphoxide alliin ('mother compound' of the active principle), which is high in garlic, A. filidens, A. barsczewskii, and A. jodanthum, but very low in the species of subgenus Melanocrommyum shown in Tab. 1 [11]. Further studies will show whether other related compounds not determined yet or completely different chemical compounds might be the reason for this usage.
Allium komarowii (Fig. 5) owns obviously a rather strong medical activity, because it is used as anabolic drug for horses [12]. Also this kind of activity could not be correlated to high cysteine sulphoxide contents [11], but this species contains a conspicuous red dye, which is chemically a sulphurpyrrol [13]. The purified substance showed a strong antioxidative effect but contribution to the health benefit of the entire plant is not clear until now.

Special dishes, which are much esteemed for strong tonic properties, are prepared from the leaves of three species of the subgenus Melanocrommyum: A. motor, A. rosenbachianum, and A. rosenorum. According to our information, these dishes are explicitly consumed because of the tonic property. Also these plants contain the above mentioned 


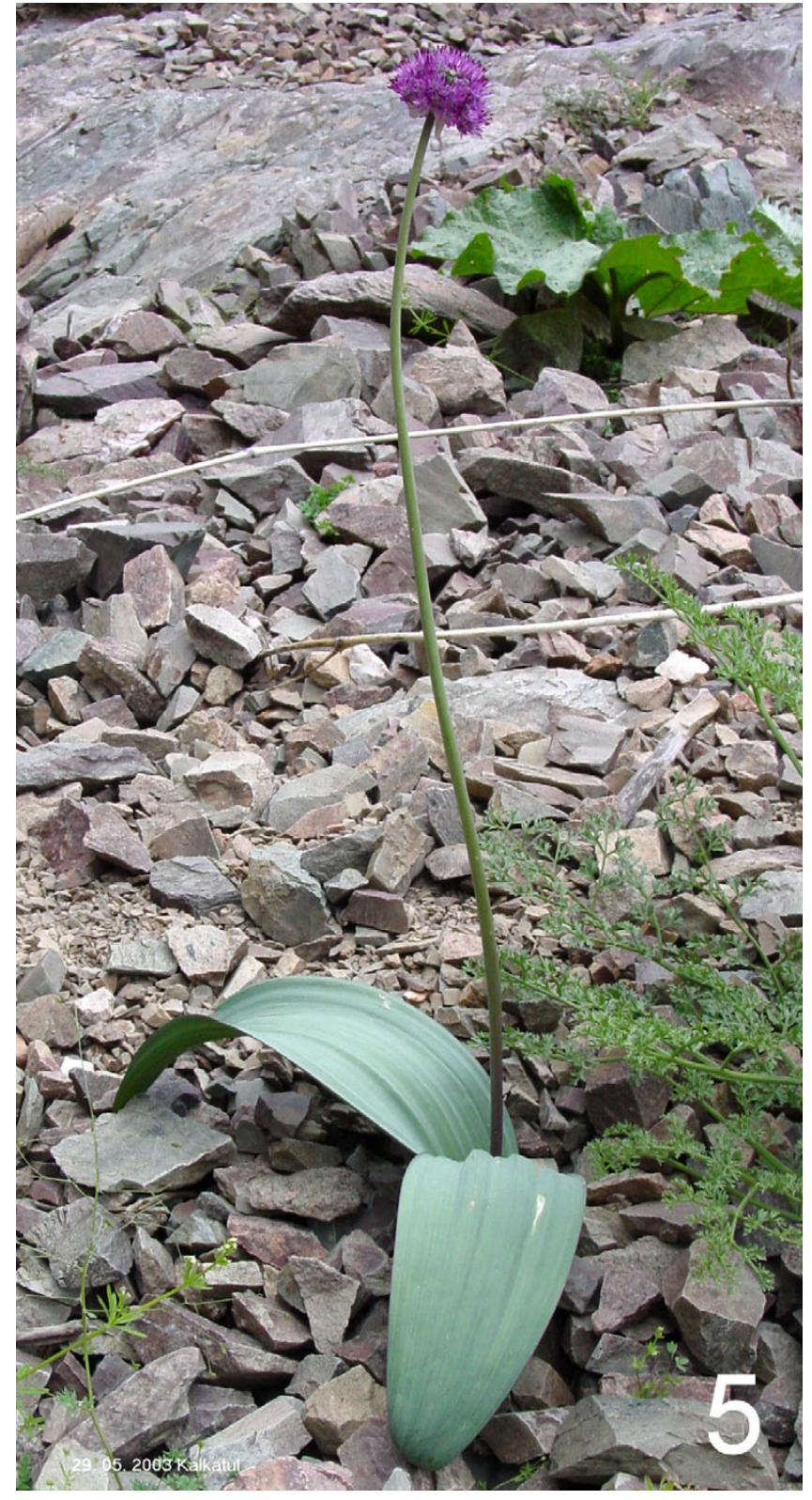

Figure 5

Another sample figure title. Flowering plant of Allium komarowii in the West Hissar mountain range (Uzbekistan).

red dye, which is regarded as a 'sign of authenticity' when the leaves are collected in April and May. The term 'motor' means 'health', but the local names of the other two species are not related to application. The questioned people always denied that these plants are used as spice.

We were only able to get confirmation that pickled young bulbs of A. stipitatum are used as spicy vegetable and not as medicine. However, young bulbs of A. suworowii are identically prepared but medicinally used. Both species contain only traces of cysteine sulphoxides [11]. Thus, we must conclude that other substances must be responsible for the differing usages also in this case.

Application against scurvy was only reported in the literature for A. talassicum and is not confirmed by own data. It can be assumed that this disease has lost importance because of a better general diet and availability of modern pharmaceuticals for treatment.

The wild Allium species listed above are mainly applied fresh or after boiling of mostly dried material (Tab. 1). Fumigation (A. fedschenkoanum) and alcoholic extraction (A. jodanthum) were only once reported.

In Uzbekistan and Tajikistan, most of the wild species shown in Tab. 1 are not simply used instead of common onion and garlic, but are very specifically applied. This fact may illustrate that collection and application of wild Allium species reflects an apparently rather ancient tradition. Several people interviewed during our expeditions underlined that often a certain plant is used by only a part of population living in a specific area, or when commonly applied species are missing in this area. The knowledge of wild Allium species was also not observed throughout a local population. Some persons questioned even did know nothing about any wild Allium species.

Because the interviews were not always successful and our research missions did not cover the whole territories of both countries, the presented data may only incompletely reflect the existing knowledge in Tajikistan and Uzbekistan. Nevertheless, we were able to find evidence that several Allium species mentioned in literature as "edible plants" without detailed specification were utilized for medical applications. Certainly some more edible wild Allium species than mentioned in Tab. 1 are also medically applied. Additional investigations seem to be essentially necessary.

\section{Competing interests}

The author(s) declare that they have no competing interests.

\section{Authors' contributions}

All authors took part in the research missions and in collecting and interpretation of the information gained. Additionally, planning and organisation the missions was managed by FOK in Uzbekistan and by $\mathrm{HH}$ in Tajikistan. RMF and FOK dealt especially with the botanical and MK with the chemical aspects of research.

\section{Acknowledgements}

Funding by VolkswagenStiftung (Hannover, Germany) under the general funding theme "Zwischen Europa und Orient - Mittelasien/Kaukasus im Fokus der Wissenschaft" is gratefully acknowledged. 


\section{References}

I. Khassanov FO: Conspectus of the wild growing Allium species of Middle Asia. In Plant life in Southwest and Central Asia Edited by: Öztürk M, Seçmen Ö, Görk G. Izmir: EGE University Press; |996:|4|-159.

2. Fritsch R: I Herkunft, Taxonomie und Geschichte von Allium. In Zwiebelanbau. Handbuch für Praxis und Wissenschaft Edited by: Fachverband Deutsche Speisezwiebel e.V. Bergen/Dumme: AgriMedia; 2005:15-37.

3. Keusgen M: Health and Alliums. In Advances in Allium science Edited by: Rabinowitch HD, Currah L. Wallingford UK: CABI Publishing; 2002:357-378.

4. Navruzshoev D: Nekotorye poleznye dikorastushchie rasteniya bassejna reki Bartang zapadnogo Pamira. Nauchnotekhn byull Vseross Inst Rasteniev 1994, 233:92-95.

5. Dadabaeva OD: Slovar nauchnykh i mestnykh nazvanij lekarstvennykh rastenij severnogo Tadzhikistana Dushanbe; 1972.

6. Kochkareva TF, Chukavina AP: Dikorastushchie pishchevye rasteniya Khovalingskogo rajona (Tsentral'nyj Tadzhikistan). Rastitel'nye resursy 1985, 2I(2): I 40-I 49.

7. Umarov TA: Dikorastushchie pishchevye rastenija gornoj chasti Tashkentskoj Oblasti. In Summary of thesis Tashkent; 1992.

8. Saidov MK: Osnovnye dikorastushchie ovoshchnye rasteniya Tsentralnogo Tadzhikistana. [The main wild vegetable plants of Central Tajikistan]. Izv AN Tadzh SSR Otdel Biol Nauk 1986, 3(104):26-30.

9. Saidov MK, Shub SS, Trofimova EP: Khimicheskaya kharakteristika osnovnikh dikorastushikh pishchevikh rastenij Tsentral'nogo Tadzhikistana. [Chemical characteristics of the main wild food plants of Central Tajikistan]. Rastitel'nye resursy 1985, 2:212.

10. Khassanov FO, Umarov TA: Dikorastushie pishchevye vidi roda Allium L. zapadnogo Tyanshanya. Uzbekskij Biologicheskij Zhurnal 1989, 6:24-25.

II. Fritsch RM, Keusgen M: Occurrence and taxonomic relations of cysteine sulphoxides in the genus Allium L. (Alliaceae). Phytochem in press.

12. Results of joint expeditions in Tajikistan. Unpublished report

13. Jedelska J, Fritsch RM, Keusgen M: Schwefelpyrrole-eine neue Naturstoffklasse in arzneilich genutzten, zentralasiatischen Allium-Arten. In Tagungsband Fachtagung für Arznei- und Gewürzpflanzen: 7. bis 9. September 2004 in Jena Edited by: Thüringer Landesanstalt für Landwirtschaft Jena. Dornburg; 2004:66-70.

14. Results of joint expeditions in Uzbekistan. Unpublished report .

15. Sakhobiddinov SS: Dikorastushchie lekarstvennye rasteniya Srednej Azii Tashkent; 1948.

16. Vvedensky Al: Semejstva Amaryllidaceae Rod 166 (I) Luk, Piez (tadzh.) - Allium L. In Flora Tadzhikskoj SSR Volume 2. Moskva - Leningrad: Izdatel'stvo Akademii Nauk SSSR; 1963:290-370.

\section{Publish with Bio Med Central and every scientist can read your work free of charge}

"BioMed Central will be the most significant development for disseminating the results of biomedical research in our lifetime. "

Sir Paul Nurse, Cancer Research UK

Your research papers will be:

- available free of charge to the entire biomedical community

- peer reviewed and published immediately upon acceptance

- cited in PubMed and archived on PubMed Central

- yours - you keep the copyright

Submit your manuscript here:

http://www.biomedcentral.com/info/publishing_adv.asp
BioMedcentral 